\title{
7. BIOSTRATIGRAPHIC AND PALEOENVIRONMENTAL STUDY OF NEOGENE AND QUATERNARY PLANKTONIC FORAMINIFERS FROM THE LOWER CONTINENTAL RISE OF THE NEW JERSEY MARGIN (WESTERN NORTH ATLANTIC), DEEP SEA DRILLING PROJECT LEG 93, SITE 603'
}

\author{
Kayed Ma'alouleh and Michel Moullade, Laboratoire de Micropaléontologie et de Géologie Marines, \\ Université de Nice ${ }^{2}$
}

\begin{abstract}
Three holes were drilled at Site 603 on the continental rise off the U.S. east coast during DSDP Leg 93. A thick Pliocene section and a few meters of lowermost Quaternary sediments were recovered in Hole 603C. A detailed biostratigraphic analysis, based on planktonic foraminiferal distribution, allowed us to delineate precisely all the Pliocene zones (sensu Berggren, 1977). The Quaternary sequence was eroded beyond Ericson's Zone P. The calculated sediment accumulation rate remained relatively high during most of the Pliocene, reaching a maximum of $150 \mathrm{~m} / \mathrm{Ma}$ in Zone PL4. Quantitative micropaleontological methods enabled us to delineate several paleoclimatic and paleoceanographic events, including those at 4.3 and $3.4 \mathrm{Ma}$.
\end{abstract}

\section{INTRODUCTION}

This chapter reports the results of a quantitative analysis of the vertical distribution of Neogene and Quaternary planktonic foraminifers recovered in Hole 603C, which was chosen for study because it was continuously cored and offered a complete section. Preliminary shipboard investigations by M. Moullade were completed ashore by K. Ma'alouleh, under the supervision of the second author.

Hole $603 \mathrm{C}$ was drilled at a water depth of $4633 \mathrm{~m}$ on the lower continental rise of the eastern U.S. coast, 270 mi. east of Cape Hatteras, at $35^{\circ} 29.78^{\prime} \mathrm{N}, 70^{\circ} 01.86^{\prime} \mathrm{W}$. (Fig. 1). In the partial Quaternary and the Pliocene section, $366 \mathrm{~m}$ (40 cores) were recovered, consisting mostly of dark claystones.

Relatively abundant and moderately well preserved populations of planktonic foraminifers, together with minor benthic assemblages, were extracted from 106 samples collected from the 40 cores of Hole 603C. Planktonic foraminiferal assemblages become progressively more impoverished and poorly preserved downhole. Increased signs of dissolution occur from Core 603C-27 downward.

A semiquantitative analysis of the planktonic foraminiferal distribution was conducted for biostratigraphic purposes. A more detailed quantitative study of 50 selected samples provided paleoclimatic and paleoceanographic interpretations.

\section{METHODS}

Samples were prepared by standard laboratory procedures, that is, they were dried, weighed, boiled in a Calgon solution, and wet-sieved with a minimum mesh size of $63 \mu \mathrm{m}$. The $>160 \mu \mathrm{m}$ fraction obtained

${ }^{1}$ van Hinte, J. E., Wise, S. W., Jr., et al., Init. Repts. DSDP, 93: Washington (U.S. Govt, Printing Office)

2 Address: Laboratoire de Micropaléontologie et de Géologie Marines, Université de Nice, Parc Valrose 06034 Nice Cedex, France. by dry-sieving was divided in two parts. One was used for the biostratigraphic study, and the relative abundance of each species was semiquantitatively estimated by visual estimation; the other was quantitatively analyzed after microsplitting the residue. At least 350 to 400 specimens were counted in each sample.

\section{BIOSTRATIGRAPHY}

\section{Planktonic Zonation}

Abundance, preservation, and stratigraphic distribution of planktonic foraminifers are shown in Figure 2. Long-ranging species, for example, those belonging to the genus Globigerina (with the exception of G. nepenthes), were intentionally omitted. Our planktonic foraminiferal zonation was established using studies by Blow (1969), Parker (1973, 1974), Stainforth et al. (1974), Berggren (1973, 1977, 1982), Berggren et al. (1983), Moullade (1983), and Kennett and Srinivasan (1983). In addition, the climatic zonation of Ericson and Wollin (1968) was applied to the Quaternary of Hole 603C.

\section{Miocene/Pliocene Boundary}

From the planktonic foraminiferal data, it is not easy to determine whether the Miocene/Pliocene boundary was recovered in Hole 603C. Common Globorotalia margaritae are already present in the bottom of the hole. This species is regarded as first appearing either in the latest Miocene or at the Miocene/Pliocene boundary (see discussion of Site 604, Moullade, this volume). Calcite dissolution strongly increases in the bottom part of Hole $603 \mathrm{C}$, and the possible climatic exclusion of other key marker species, such as Globoquadrina dehiscens and the Globorotalia merotumida-plesiotumida lineage, also prevents recognition of the boundary. The distribution of planktonic foraminifers from Cores 603C-35 (lower part) to $603 \mathrm{C}-40$ suggests that this interval includes the acme of G. margaritae and thus belongs to Subzone PLla (earliest Pliocene). 


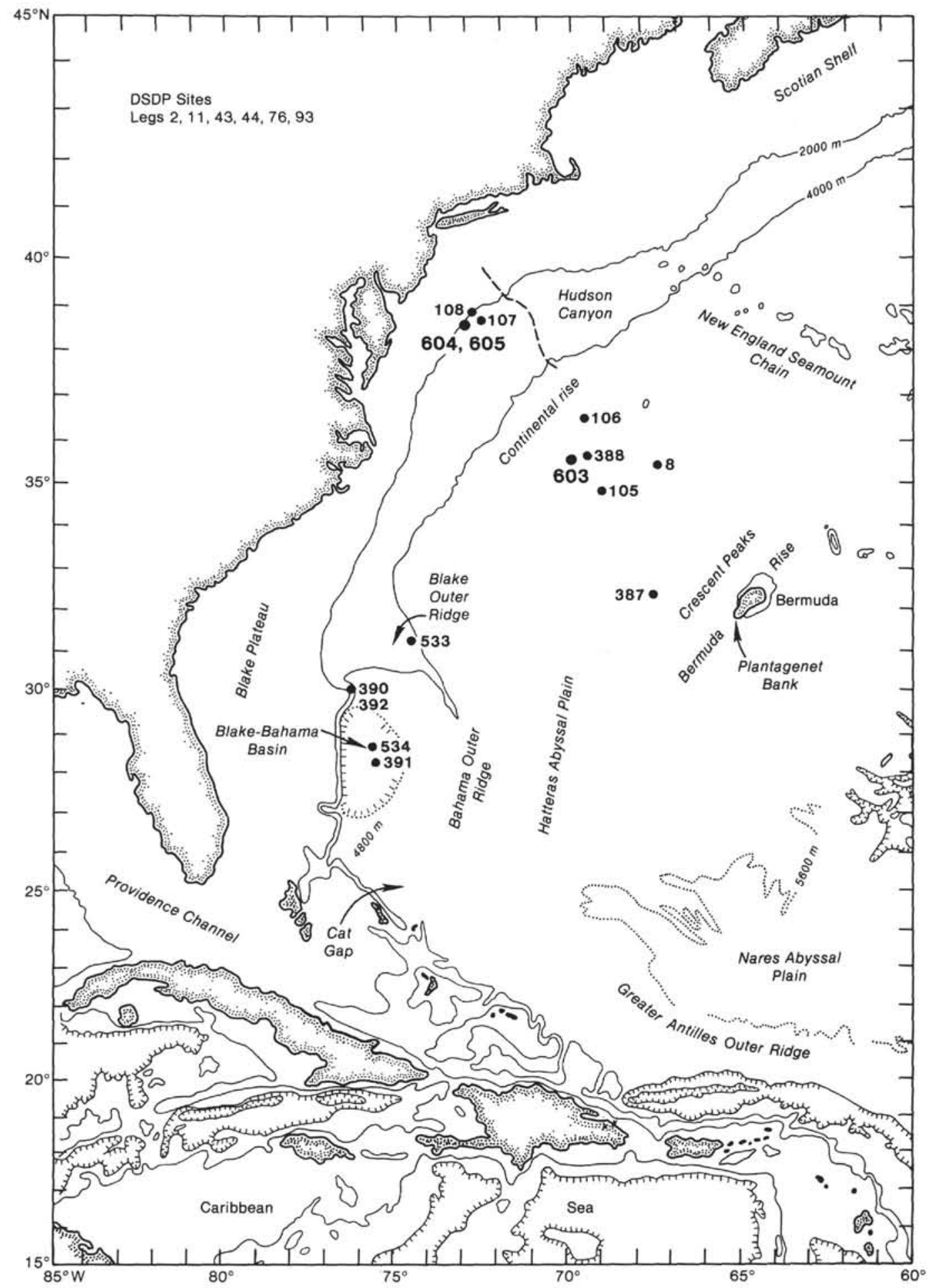

Figure 1. Location of Site 603 and earlier DSDP sites drilled in the northwest Atlantic.

Pliocene

All the Pliocene zones (sensu Berggren, 1977) were identified in Hole $603 \mathrm{C}$ (Fig. 2). The boundary between Zones PL1 and PL2 was placed between Cores 603C-27 and $603 \mathrm{C}-28$, based upon the last appearance datum (LAD) of Globigerina nepenthes in Sample 603C-28-3,
90-94 cm. More difficulties arise in trying to delineate precisely the three subzones of Zone PL1, as defined by Berggren (1977). The lower limit of the upper Subzone, PL1c is placed between Cores $603 \mathrm{C}-30$ and -31 by the first occurrence of Globorotalia gr. crassaformis in Sample $603 \mathrm{C}-30, \mathrm{CC}$. The first appearance datum (FAD) of G. puncticulata defines the lower limit of Subzone PL1b. 
Probably because of climatic control, this temperate to cold-water species occurs only sporadically in Hole 603C. Its first occurrence in Sample 603C-35-3, 90-94 cm may be nonevolutionary, and the position of the PL1a/PL1b subzonal boundary in Core $603 \mathrm{C}-35$ is slightly uncertain.

The PL2/PL3 boundary was placed in the middle of Core 603C-25, based upon the highest occurrence of $G$. margaritae in Sample 603C-25-5, 90-94 cm. The PL3/ PL4 boundary was defined by Berggren $(1973,1977)$ as the concomitant FAD of Sphaeroidinella dehiscens s.s. and LAD of Sphaeroidinellopsis spp. (i.e., seminulina group). In Hole $603 \mathrm{C}$ the former species first appears in Sample 603C-20-2, 90-94 cm and the latter becomes extinct in Sample 603C-21-3, 90-92 cm. We therefore tentatively place this boundary in the middle of Core $603 \mathrm{C}-20$.

The boundary between Zones PL4 and PL5, based upon the LAD of Dentoglobigerina altispira, occurs between Samples 603C-15-3, 90-92 cm and 603C-15-4, 90-94 cm. The PL5/PL6 zonal boundary is placed between Samples 603C-8-3, 90-93 cm and 603-8-5, 90-93 $\mathrm{cm}$, because $G$. miocenica last appears in the latter sample.

\section{Pliocene/Pleistocene Boundary}

Preliminary shipboard investigations based on both foraminifer and nannofossil distribution demonstrated that the Pliocene/Quaternary boundary should be placed between Cores $603 \mathrm{C}-4$ and -5 . Shore-based studies confirm that Globorotalia truncatulinoides, a Quaternary index-form in the North Atlantic mid-latitudes, first appears in this interval-more precisely, in Sample 603C$5-2,90-94 \mathrm{~cm}$.

\section{Quaternary}

Only about $30 \mathrm{~m}$ of Quaternary sediments were penetrated in Hole 603C. Globorotalia tosaensis co-occurs sporadically with $G$. truncatulinoides in Cores $603 C-4$ to $603 \mathrm{C}-1$, thus making it possible to attribute these sediments to the lower Pleistocene. A very thin layer of Recent deposits, however, may overlie the lower Pleistocene beds: a warm-water, Holocene and/or Recent as- semblage consisting of G. truncatulinoides, G. gr. menardii-tumida, G. hirsuta, Pulleniatina obliquiloculata, $P$. finalis, G. ungulata, and common Globigerinoides ruber f. rosea was found in a sample taken from the very top of Core $603 \mathrm{C}-1$.

By using the Globorotalia menardii-tumida complex abundance curve (Fig. 3) (cf. Briskin and Berggren, 1975), we identified the first two intervals of Ericson's zonation in the lower Pleistocene part of Hole 603C. The first interval, not labelled by Ericson and Wollin (1968) and named Zone "O" by Moullade (Site 604, this volume), corresponds to the upper part of Core $603 \mathrm{C}-5$, Core $603 \mathrm{C}-4$, and the lower part of Core 603C-3 (upper limit of Zone "O": Sample 603C-3-3, 100-104 cm). The second interval includes the upper part of Core 603C-3, Cores 603C-2, and Core 603-1 (with the exception of the topmost sediment, previously mentioned) and represents most of Zone P. These results demonstrate that only the basal part of the lower Pleistocene is present in Hole $603 \mathrm{C}$.

\section{Correlation with Magnetostratigraphic Data}

The main magnetostratigraphic datums (observations in Hole $603 \mathrm{C}$ from Canninga et al., this volume) are plotted versus numerical ages (calibration of magnetic anomalies from Lowrie and Alvarez, 1981; Hsü et al., 1984 ) in Figure 4. Assuming that the magnetic chronology is correct, we can calibrate the ages of the planktonic foraminiferal datums in Hole $603 \mathrm{C}$ by plotting their sub-bottom depths on the same curve. In Table 1 our observations are compared with recent age estimations of these planktonic foraminiferal datums, established mainly in the South Atlantic (Berggren, 1977; Berggren, et al., 1983). It appears that there exists an important diachrony, particularly for the middle and late Pliocene, between the subtropical South Atlantic zonation scheme and that at $35^{\circ} \mathrm{N}$ in the North Atlantic.

\section{Sediment Accumulation Rate}

The curve shown in Figure 4 also permits us to calculate the sediment accumulation rate (uncorrected for compaction) in Hole $603 \mathrm{C}$. This curve may be broken into

Table 1. Numerical calibration of main Pliocene-earliest Quaternary biostratigraphic datums (South Atlantic Ocean; Site 603).

\begin{tabular}{|c|c|c|c|c|}
\hline \multirow[b]{2}{*}{ Datum } & \multirow[b]{2}{*}{ Top of zone } & \multicolumn{3}{|c|}{ Age (Ma) } \\
\hline & & $\begin{array}{l}\text { Berggren, } \\
1977\end{array}$ & $\begin{array}{c}\text { Berggren et al., } \\
1983\end{array}$ & $\begin{array}{l}\text { This } \\
\text { chapter }\end{array}$ \\
\hline "O"/P zonal boundary & “O” & 1.75 & & 1.68 \\
\hline Globorotalia truncatulinoides FAD & PL6 & 1.8 & 1.9 & 1.8 \\
\hline G. miocenica LAD & PL5 & 2.2 & 2.1 & 2.23 \\
\hline Dentoglobigerina altispira LAD & PL4 & 2.8 & 2.5 & 2.95 \\
\hline $\begin{array}{l}\text { Sphaeroidinella dehiscens FAD, } \\
\text { Sphaeroidinellopsis spp. LAD }\end{array}$ & PL3 & 3.0 & 2.8 & 3.38 \\
\hline G. margaritae $\mathrm{LAD}$ & PL2 & 3.3 & 3.4 & 3.8 \\
\hline Globigerina nepenthes LAD & PLlc & 3.7 & 3.6 & 4.1 \\
\hline Globorotalia crassaformis FAD & PLib & 4.0 & 4.2 & 4.28 \\
\hline G. puncticulata FAD & PL1a & 4.6 & 4.4 & 4.76 \\
\hline
\end{tabular}

Note: $\mathrm{FAD}=$ first appearance datum, $\mathrm{LAD}=$ last appearance datum. 


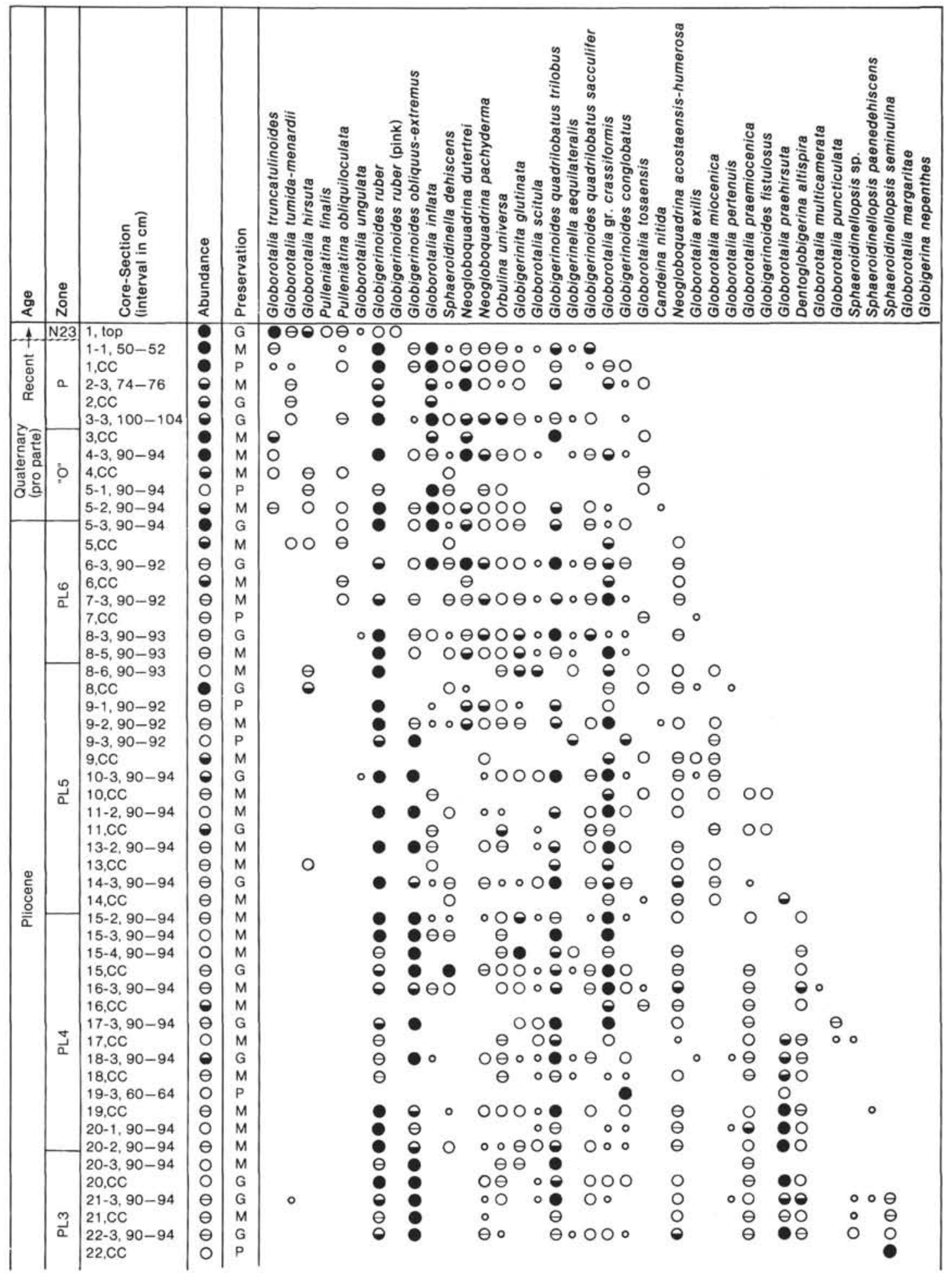

Figure 2. Semiquantitative stratigraphic distribution of planktonic foraminiferal species in samples from Hole $603 \mathrm{C}$.

five segments, corresponding to five periods in which sedimentation rates are relatively constant:

1. From 5.2 to $3.4 \mathrm{Ma}$ (= Zones PL1 to PL3), with a rapid sedimentation rate averaging $100 \mathrm{~m} / \mathrm{Ma}$.

2. From 3.4 to $3.2 \mathrm{Ma}$ (= lower part of Zone PL4), characterized by a very rapid rate approaching $150 \mathrm{~m} /$ Ma.
3. From 3.2 to $2.9 \mathrm{Ma}$ (= upper part of Zone PL4), with a rate of $100 \mathrm{~m} / \mathrm{Ma}$.

4. From 2.9 to $1.9 \mathrm{Ma}$ (= upper Pliocene Zones PL5 and PL6), in which the sedimentation rate decreases to $70 \mathrm{~m} / \mathrm{Ma}$.

5. From 1.9 to $1.7 \mathrm{Ma}$ (= lowermost Pleistocene), with about $150 \mathrm{~m} / \mathrm{Ma}$, as in period 2 . 


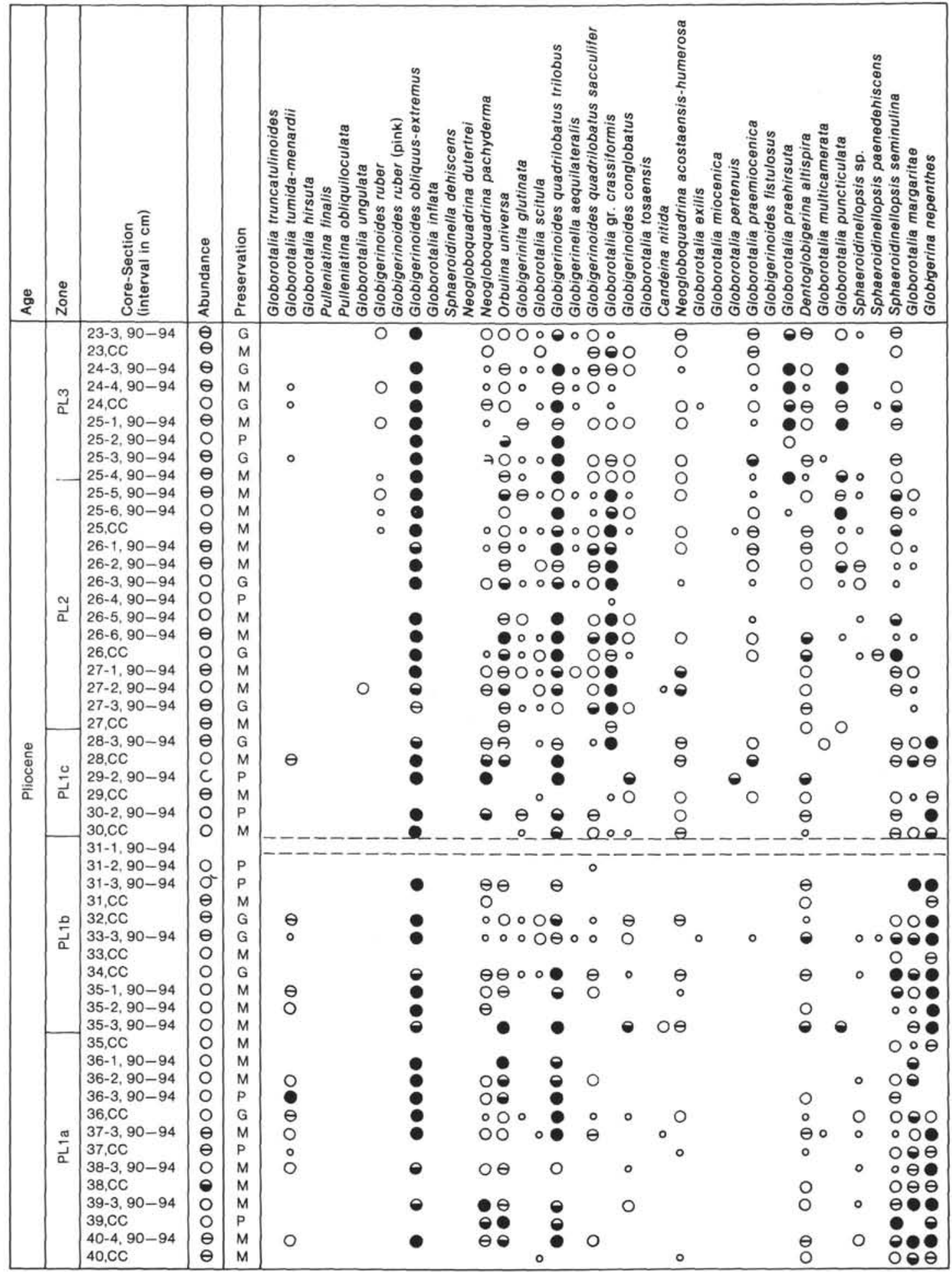

Abundance: abundant, $>10 \%$; common, $5-10 \%$; $\Theta$ few, $3-5 \%$ Orare, $1-2 \% ;$ o very rare, $0-1 \%$ Preservation: $\mathrm{G}=$ good, $\mathrm{M}=$ moderate, $\mathrm{P}=$ poor

Figure 2 (continued).

The marked increase in the sedimentation rate that occurs between the upper Pliocene and the basal Quaternary of Hole $603 \mathrm{C}$ is consistent with data obtained from neighboring DSDP Site 106 (Hollister, Ewing, et al., 1972), where $350 \mathrm{~m}$ of Quaternary sediments were penetrated (a calculated rate of $195 \mathrm{~m} / \mathrm{Ma}$ ).

\section{PALEOCLIMATOLOGY AND PALEOCEANOGRAPHY}

Quantitative parameters based on variations of both planktonic and benthic foraminiferal abundance are shown in Figure $5 \mathrm{~A}-\mathrm{C}$. In Figure 5D are indicated vari- 


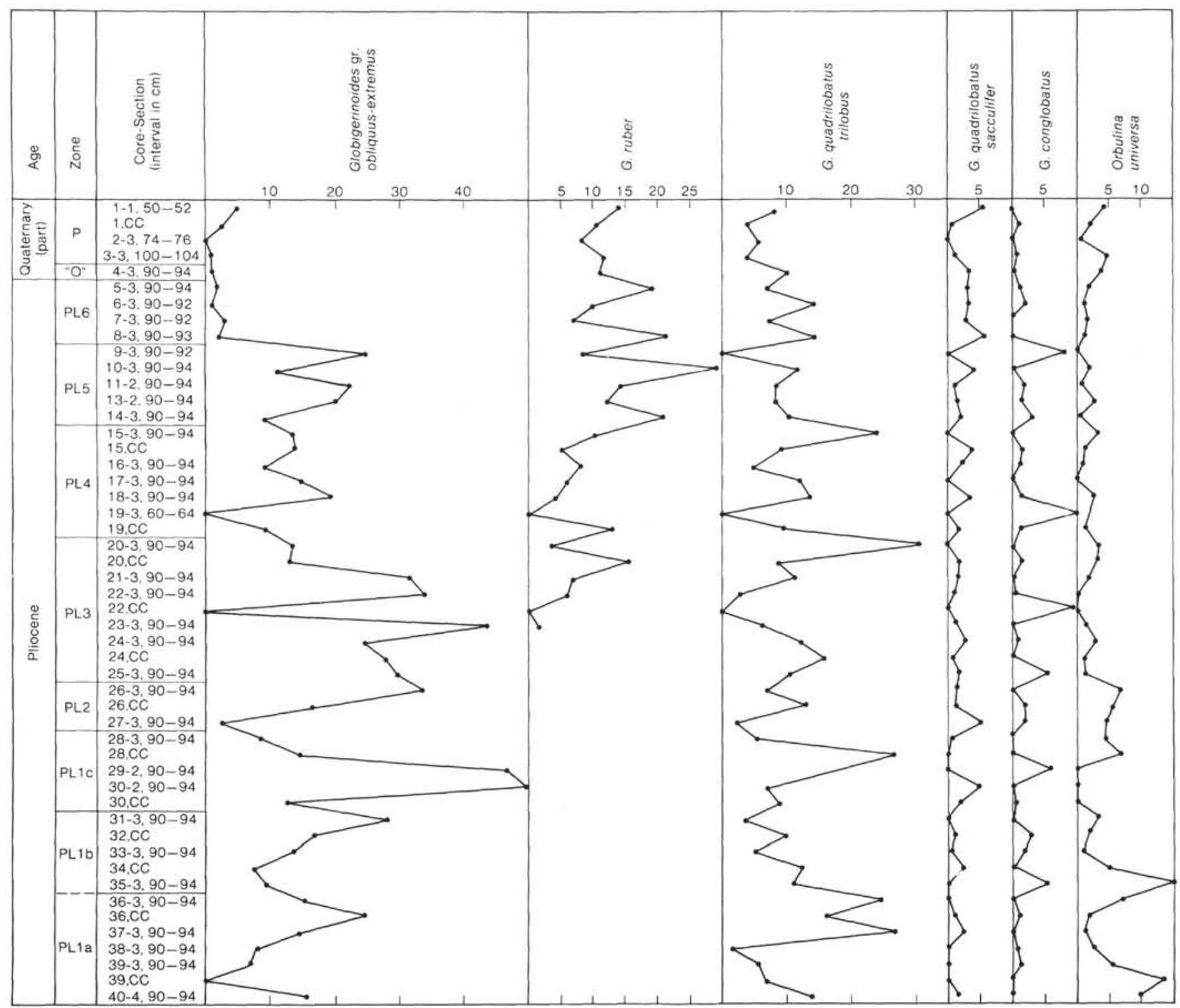

Figure 3. Quantitative distribution (in percentages) of planktonic foraminiferal species in the $>160 \mu \mathrm{m}$ size fraction from selected samples of Hole $603 \mathrm{C}$.

ations in the percentage of planktonics (of total foraminifers). In addition, Figure 6 shows variations in the number of planktonic species (planktonic diversity).

The shape of these curves demonstrates a distinct contrast between the Pliocene and the Quaternary of Hole 603C.

The Pliocene foraminiferal assemblages are marked by few specimens, averaging less than $25 / \mathrm{g}$. The number of foraminifers increases slightly in the middle-late Pliocene, with a few moderate peaks of less than 100 specimens/g. Both planktonic and benthic foraminifers show similar patterns. The paucity of Pliocene foraminifers may be consistent with the high sediment accumulation rates depicted in Figure 4 and can be interpreted as resulting from sedimentary dilution of the microfauna. During the same Pliocene period, percentages of planktonic foraminifers (Fig. 5D) and the planktonic diversity (Fig.
6) show many oscillations attributable to fluctuations of the CCD (cf. Moullade, Site 604, this volume).

In the upper part of Zone PL6 and the lowest Quaternary, planktonic foraminiferal percentages markedly increase to values of $>95 \%$. Almost simultaneously, the total number of foraminifers and the number of planktonic specimens sharply increase with two peaks of several hundred of specimens per gram. Even the benthic foraminifers appear to be proportionally more abundant at these levels than deeper in the hole: instead of an average value of 1 to 2 specimens/g and maximums of 3, two small peaks of almost 8 specimens/g are observed. Figure 4 showed that the sediment accumulation rate remained high and even increased compared to that of the Pliocene during the early Quaternary in Hole 603C. We may thus eliminate condensed sedimentation as a possible explanation for this sudden enrichment in foramini- 


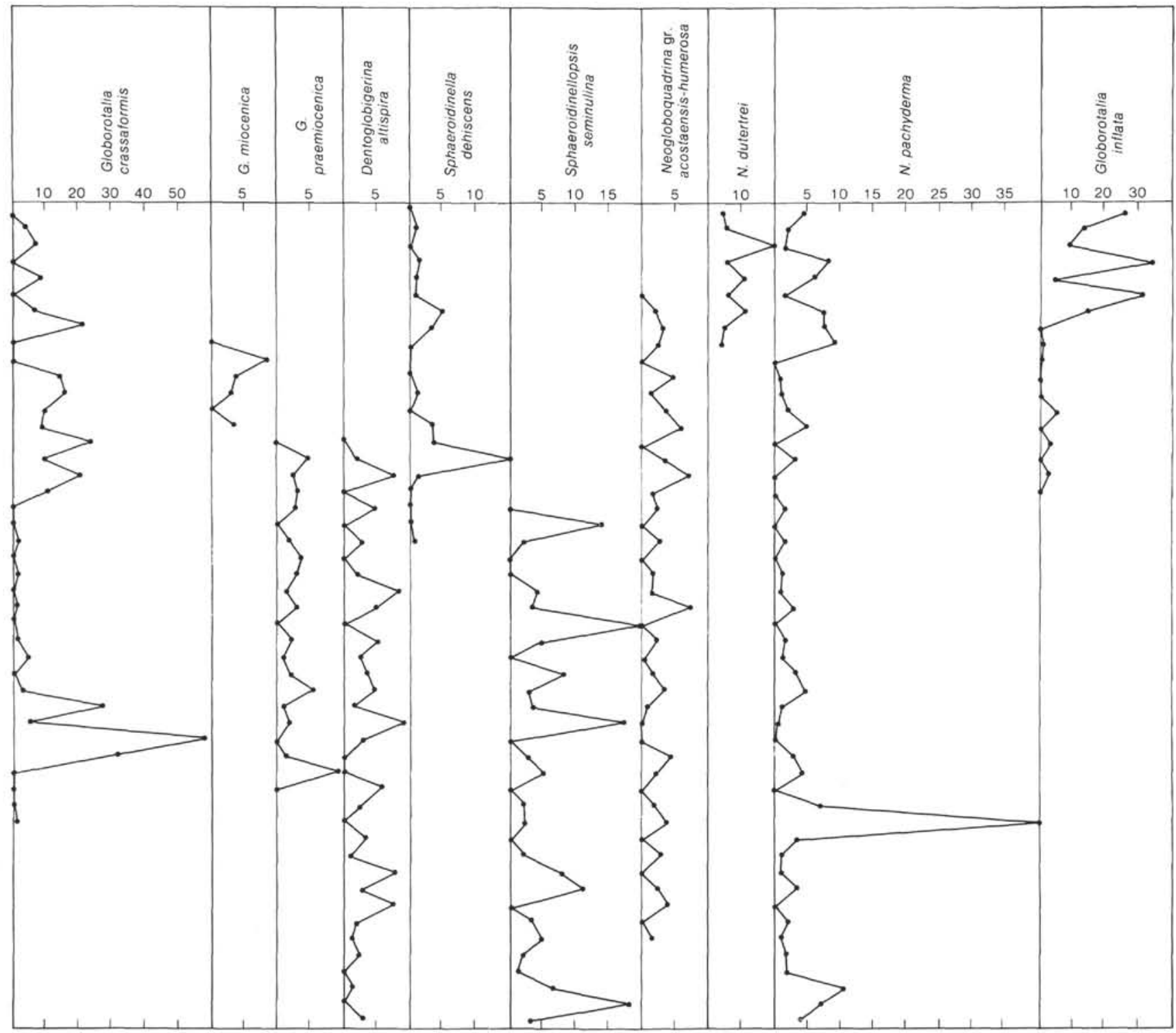

Figure 3 (continued).

fers. The increase in the percentage of planktonic foraminifers at the top of Zone PL6 and during Ericson's Zone $\mathrm{P}$, which is considered to be a warmer episode, leads us to suggest that this change is due to increased productivity accompanied by a deepening of the CCD.

These data, combined with quantitative data for planktonic foraminiferal species (Fig. 3), enable us to identify three main climatic events in the sequence drilled at Hole 603C.

1. A sharp decrease in both planktonic diversity and the abundance of Globigerinoides trilobus (a warm-water species), as well as a strong increase in the frequency of Neogloboquadrina pachyderma (a cold-water but also dissolution-resistant species), occur in the interval corresponding to the top of Subzone PL1b (Cores 603C-30 to 32 ), at about $4.3 \mathrm{Ma}$ according to magnetostratigraphy (see Fig. 4). Such a change was also depicted close to the PL1b/PL1c subzonal boundary at Site 604 (Moullade, this volume). The only significant paleoceanographic event that occurred at this time is the uplift of the Isthmus of Panama (Berggren, 1982; Keigwin, 1979, 1982), which isolated the Atlantic Ocean from the Pacific. No marked early Pliocene cold event seems to have been clearly documented.

2. Another similar crisis clearly occurs at the PL3/ PL4 zonal boundary, from Core 603C-19 up, as is shown by shifts in several parameters: a sudden drop in planktonic diversity, more frequent oscillations in the percentage of planktonic specimens, and a sharp decrease in the abundance of Globigerinoides spp. (trilobus, ruber, gr. obliquus). A sudden crisis also occurs at the same biostratigraphic level in Site 604 (Moullade, this volume), that is, at the PL3/PL4 boundary, here located at 3.4 Ma (see Table 1).

3. The third paleoclimatic and/or paleoceanographic event that may be depicted in Hole $603 \mathrm{C}$ is a latest Pliocene (upper part of Zone PL6) "warming." This is revealed by the evolution of the parameters shown in 


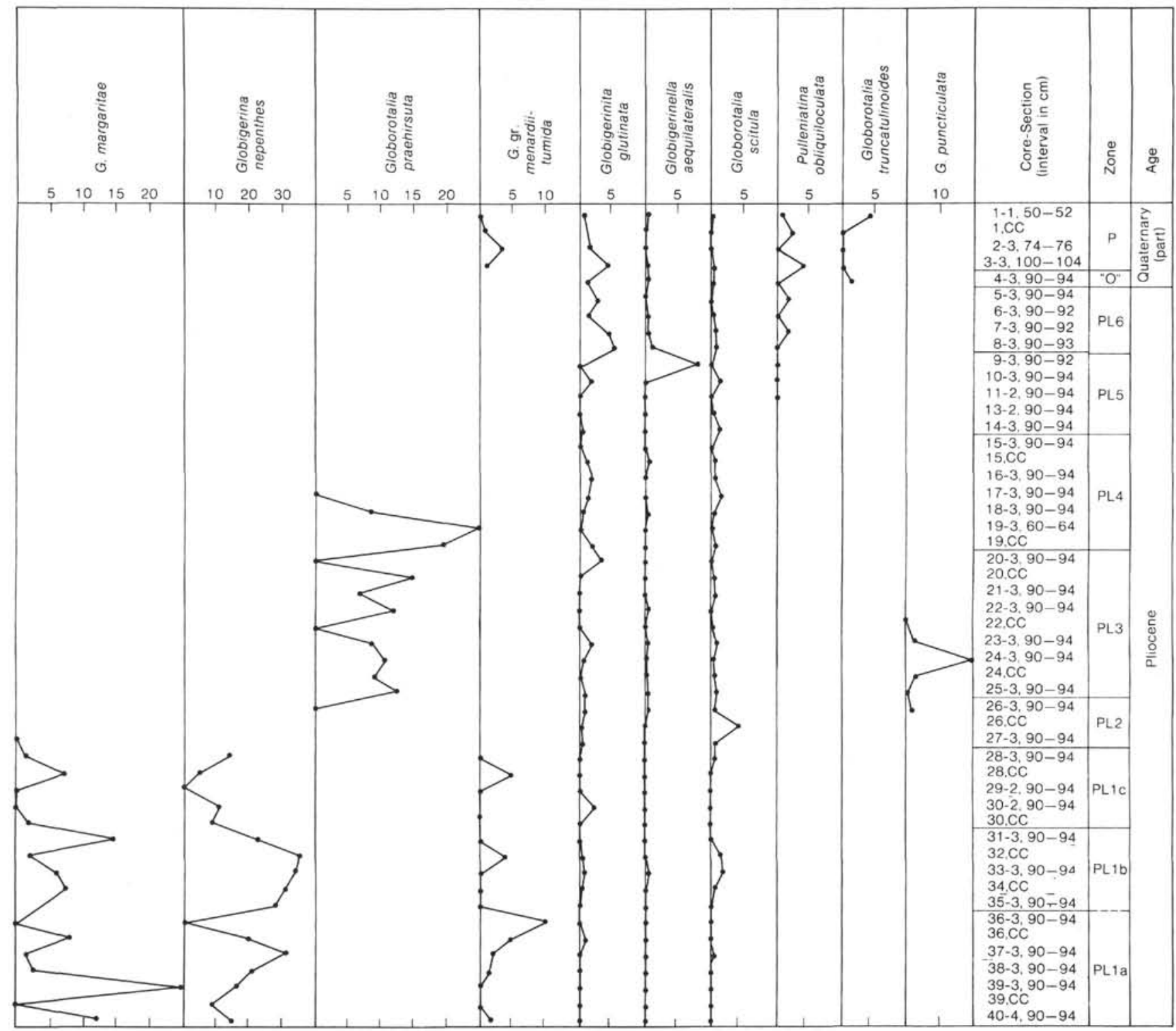

Figure 3 (continued).

Figure 5, but does not seem to be clearly indicated at the specific level (Fig. 3).

\section{CONCLUSION}

Quantitative investigations of at least two samples per core have made it possible for us to define a detailed biostratigraphy, to correlate biostratigraphic and magnetostratigraphic datums and to insert several events, depicted by quantitative micropaleontological methods, into the chronological framework. Further isotopic studies using a closer sample spacing, should make possible a better understanding of their paleoceanographic and paleoclimatic significance. However, taking into account the results obtained by Keller et al. (1982) in the Pacific Ocean, we suggest that the dissolution crises that appear to have occurred contemporaneously at various sites may be interpreted as evidence of climatic cooling.

\section{ACKNOWLEDGMENTS}

M. Moullade thanks DSDP for inviting him to participate on Leg 93. The authors also thank Dr. R. K. Olsson and Dr. Dean A. Dunn for reviewing the manuscript of this paper.

Financial support for this study was provided by the Centre National de la Recherche Scientifique under Grants ATP Géologie-Géophysique des Océans no. 318/366 and Jeune Equipe no. 333.

\section{REFERENCES}

Berggren, W. A., 1973. The Pliocene time-scale: calibration of planktonic foraminiferal and calcareous nannoplankton zones. Nature, 243(5407):391-397.

1977. Late Neogene planktonic foraminiferal biostratigraphy of the Rio Grande Rise (South Atlantic). Mar. Micropaleontol., 2:265-313.

1982. Neogene planktonic foraminiferal biostratigraphy and biogeography: Atlantic, Mediterranean and Indo-Pacific regions. In Tsuchi, R. (Ed.), Pacific Neogene Datum Planes. IGCP Project 114: Tokyo (Univ. Tokyo Press), 111-161. 
Berggren, W. A., Aubry, M. P., and Hamilton, N., 1983. Neogene magnetobiostratigraphy of Deep Sea Drilling Project 516 (Rio Grande Rise, South Atlantic). In Barker, P. F., Carlson, R. L., Johnson, D. A., et al., Init. Repts. DSDP, 72: Washington (U.S. Govt. Printing Office), 675-713.

Blow, W. H., 1969. Late Middle Eocene to Recent planktonic foraminiferal biostratigraphy. In Brönnimann, P., and Renz, H. H. (Eds.), Proc. Ist. Int. Conf. Planktonic Microfossils Geneva, 1967: (Vol. 1) Leiden (E. J. Brill), 199-421.

Briskin, M., and Berggren, W. A., 1975. Pleistocene stratigraphy and quantitative paleoceanography of tropical North Atlantic core V16205. In Saito, T., and Burckle, L. H. (Eds.), Late Neogene Epoch Boundaries (Vol. 1): New York (American Museum Natural History), 167-198.

Ericson, D. B., and Wollin, G., 1968. Pleistocene climates and chronology in deep-sea sediments. Science, 162(3859):1227-1234.

Hollister, C. D., Ewing, J. 1., et al., 1972. Init. Repts. DSDP, 11: Washington (U.S. Govt. Printing Office).

Hsü, K. J., LaBrecque, J., Percival, S. F., Wright, R. C., Gombos, A. M., Pisciotto, K., Tucker, P., Peterson, N., McKenzie, J. A., Weissert, H., Karpoff, A. M., Carman, M. F., Jr., and Schreiber, E., 1984. Numerical ages of Cenozoic biostratigraphic datum levels: results of South Atlantic Leg 73 drilling. Geol. Soc. Am. Bull., 95: 863-876.

Keigwin, L. D., Jr., 1979. Late Cenozoic stable isotope stratigraphy and paleoceanography of DSDP Sites from the east equatorial and central-North Pacific Ocean. Earth Planet. Sci. Lett., 45:361-382.

, 1982. Isotopic paleoceanography of the Caribbean and East Pacific: role of Panama uplift in Late Neogene time. Science, 217: $350-353$.
Keller, G., Barron, J. A., and Burckle, L. H., 1982. North Pacific late Miocene correlations using microfossils, stable isotopes, percent $\mathrm{CaCO}_{3}$, and magnetostratigraphy. Mar. Micropaleontol., 7:327-357.

Kennett, J. P., and Srinivasan, M. S., 1983. Neogene Planktonic Foraminifera: A Phylogenetic Atlas: Stroudsburg, PA (Hutchinson Ross Publishing Company).

Lowrie, W., and Alvarez, A., 1981. One hundred million years of geomagnetic polarity history. Geology, 9:392-397.

Moullade, M., 1983. Upper Neogene and Quaternary planktonic foraminifers from the Blake Outer Ridge and Blake-Bahama Basin (Western North Atlantic), Deep Sea Drilling Project Leg 76, Sites 533 and 534. In Sheridan, R. E., Gradstein, F. M., et al., Init. Repts. DSDP, 76: Washington (U.S. Govt. Printing Office), 511535.

Parker, F. L., 1973. Late Cenozoic biostratigraphy (planktonic Foraminifera) of tropical Atlantic deep-sea sections. Rev. Espan. Micropaleontol., 5:253-289.

1974. Upper Neogene biostratigraphy (planktonic foraminifera) of DSDP Sites 139 and 141. J. Foraminiferal Res., 4:9-15.

Stainforth, R. M., Lamb, J. L., Luterbacher, H. P., Beard, J. H., and Jeffords, R. M., 1974. Cenozoic Planktonic Foraminiferal Zonation and Characteristics of Index Forms. Univ. Kansas Paleontol. Contrib., 32 .

Date of Initial Receipt: 11 February 1985

Date of Acceptance: 2 January 1986

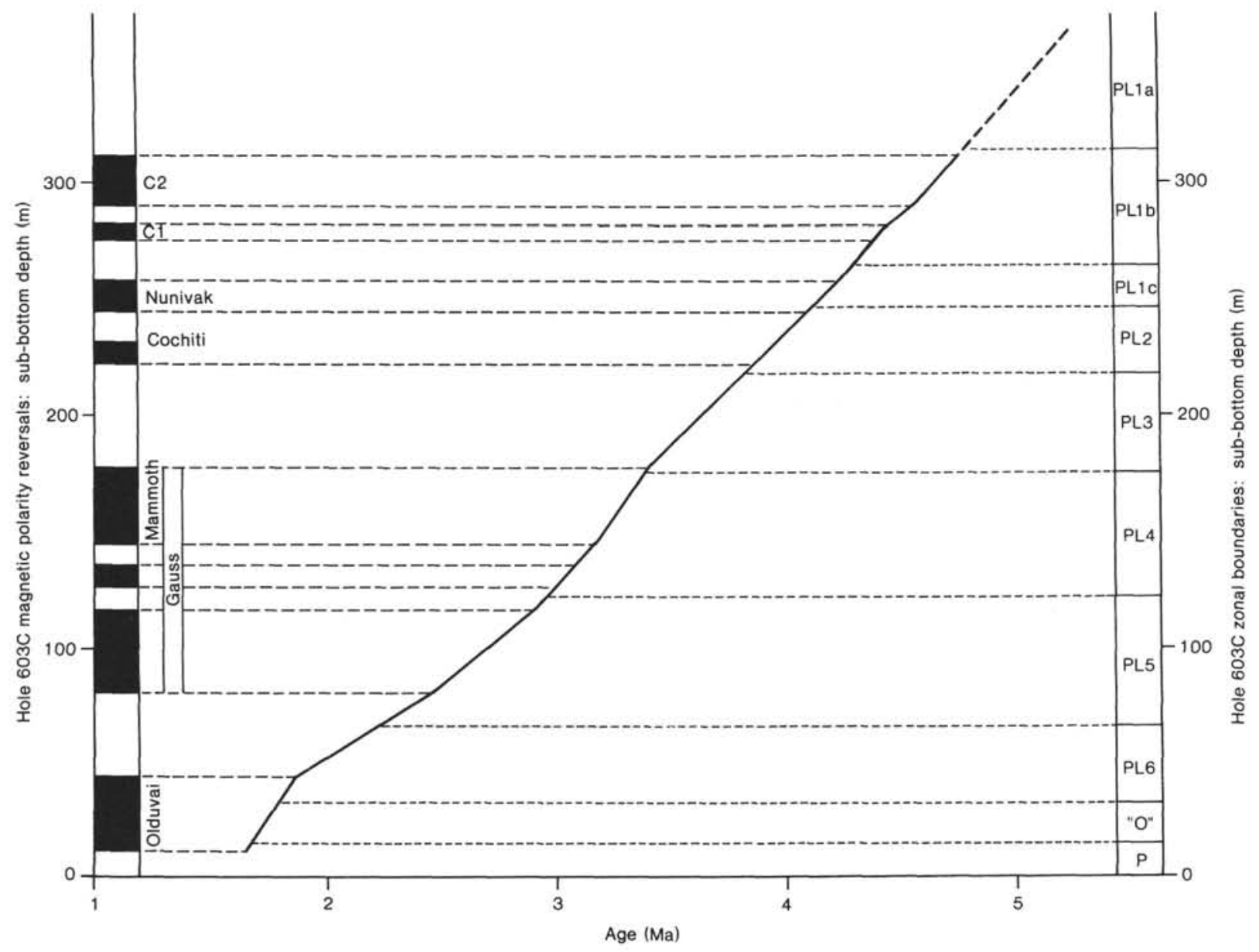

Figure 4. Correlation of biostratigraphic datums (this chapter) with magnetostratigraphic data (Canninga et al., this volume), Hole 603C. Calibration with numerical ages mainly from Lowrie and Alvarez (1981), and Hsü et al. (1984). 


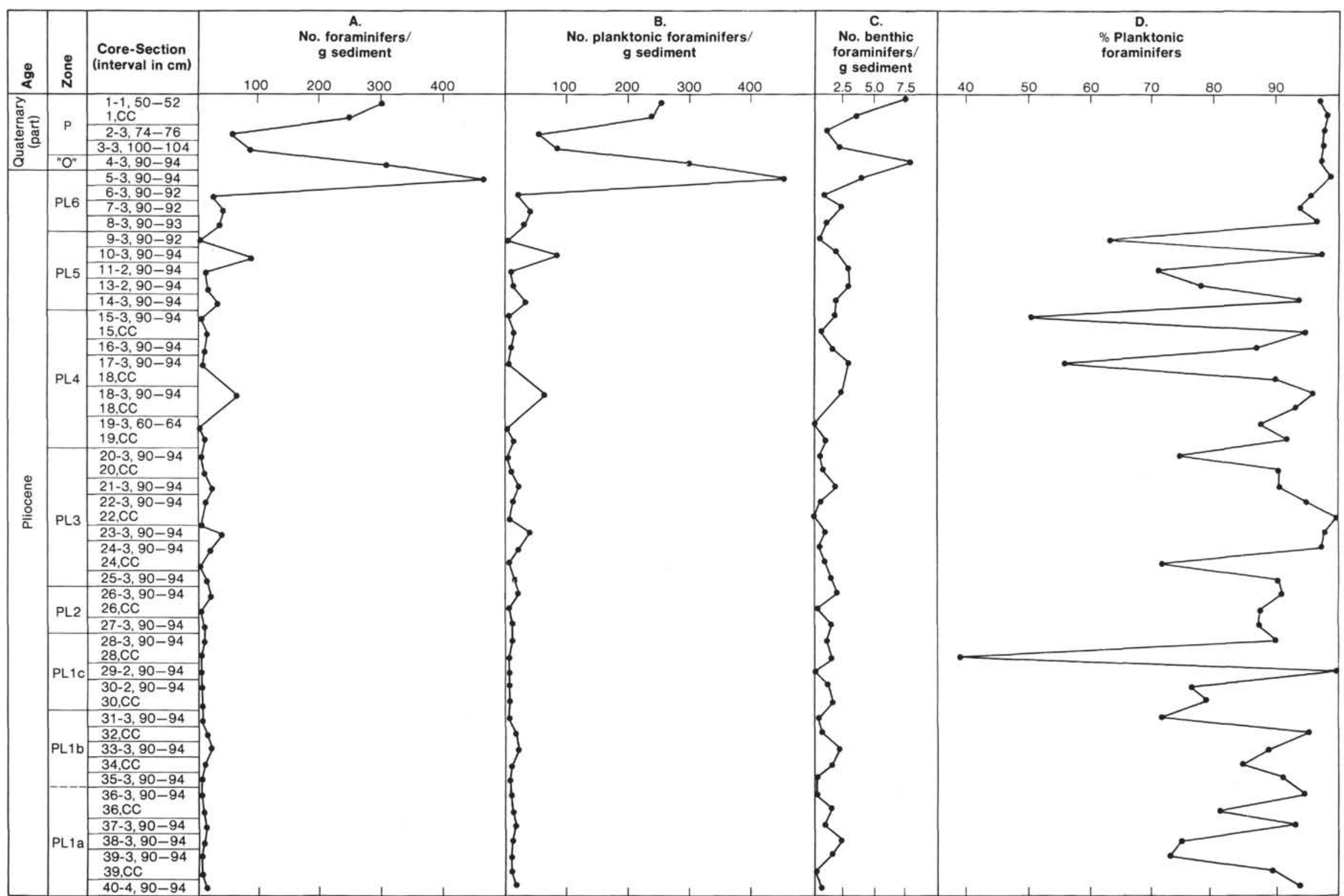

Figure 5. Characteristics of samples from Hole $603 \mathrm{C}$ ( $>160 \mu \mathrm{m}$ size fraction). 
NEOGENE AND QUATERNARY PLANKTONIC FORAMINIFERS, SITE 603

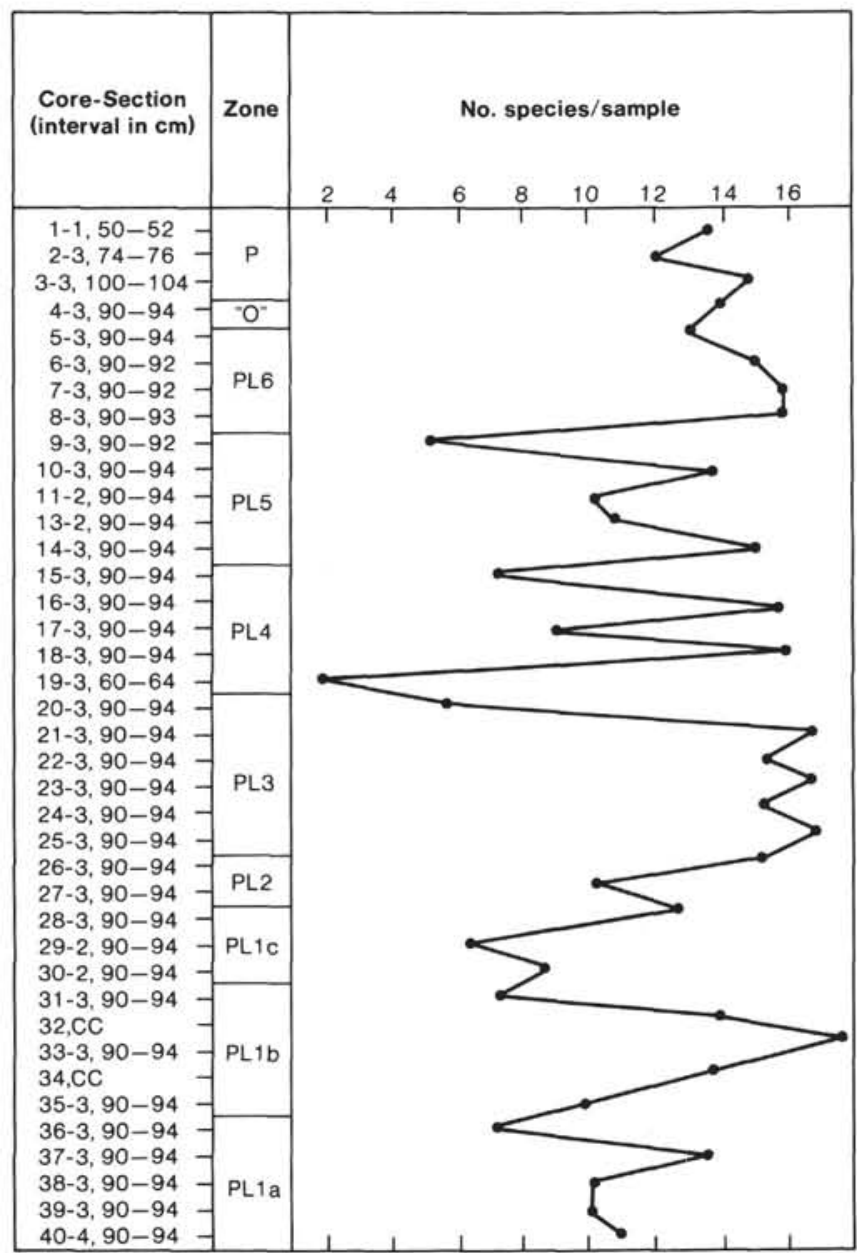

Figure 6. Variation in planktonic foraminiferal species diversity, Hole $603 \mathrm{C}$. 